\title{
Changes in the geographical distribution of Microtus (Iberomys) cabrerae (Thomas, 1906) from the Late Pleistocene to the Holocene
}

\author{
Juan Manuel LÓPEZ-GARCÍA ${ }^{1,2, *}$ \& Gloria CUENCA-BESCÓS ${ }^{3}$ \\ ${ }^{1}$ IPHES, Institut Català de Paleoecologia Humana i Evolució Social, C/Escorxador s/n, E- 43003 Tarragona, Spain; jmlopez@iphes.cat \\ 2 Àrea de Prehistòria, Universitat Rovira i Virgili (URV), Avinguda de Catalunya 35, E-43002 Tarragona, Spain \\ ${ }^{3}$ Aragosaurus-IUCA, Dpto. Ciencias de la Tierra, Universidad de Zaragoza, E-50009 Zaragoza, Spain. cuencag@unizar.es \\ * Corresponding author
}

López-García, J. M. \& Cuenca-Bescós, G. 2012. Changes in the geographical distribution of Microtus (Iberomys) cabrerae (Thomas, 1906) from the Late Pleistocene to the Holocene. [Cambios en la distribución geográfica de Microtus (Iberomys) cabrerae (Thomas, 1906) del Pleistoceno superior al Holoceno]. Spanish Journal of Palaeontology, 27 (2), 117-124.

Manuscript received 21 April 2012

Manuscript accepted 27 September 2012

(C) Sociedad Española de Paleontología ISSN 2255-0550

\begin{abstract}
Cabrera's vole, Microtus (Iberomys) cabrerae, is a currently endemic species restricted to Spain and Portugal. Its presentday distribution is fragmentary, but in the past it was broadly distributed across the Iberian Peninsula, with the exception of the northern part of the Peninsula. Various hypotheses have been expounded to explain the retraction of the species since the beginning of the Holocene: 1) the climate changes produced in the Bronze Age; 2) the human impact on the restricted habitat of the species; and 3) its direct competition with other species with similar environmental requirements, such as the southern water vole (Arvicola sapidus), an Iberian endemism. In this paper, we discuss these hypotheses regarding the distribution of the species fossil record in the Late Pleistocene and beginning of the Holocene, as well as its current distribution. The most plausible hypothesis for its retraction is human impact, which has destroyed the habitat of the species with the development of agriculture and road infrastructures and the increasing human population.
\end{abstract}

Keywords: Microtus (Iberomys) cabrerae, distribution changes, climate, human impact, competition with other species.

\section{RESUMEN}

El topillo de Cabrera, Microtus (Iberomys) cabrerae, es una especie actual endémica restringida a España y Portugal. Su distribución actual es fragmentaria, pero en el pasado estuvo ampliamente extendida a lo largo de la Península Ibérica, con la excepción de parte del norte peninsular. Varias hipótesis han sido formuladas para explicar la retracción de la especie desde inicios del Holoceno: 1) los cambios climáticos producidos en la Edad del Bronce; 2) el impacto humano en el hábitat restringido de la especie; y 3) la competencia directa con otras especies de requerimientos ambientales similares, como la rata de agua (Arvicola sapidus), un endemismo Ibérico. En este artículo se discuten estas hipótesis teniendo en cuenta la distribución del registro fósil de la especie durante el Pleistoceno superior e inicios del Holoceno, así como su distribución actual. La hipótesis más plausible para la retracción de la especie es el impacto humano, que ha destruido progresivamente el hábitat de la especie con el desarrollo de la agricultura, las infraestructuras viarias y el incremento de la población humana.

Palabras clave: Microtus (Iberomys) cabrerae, cambios en la distribución, clima, impacto humano, competencia con otras especies. 


\section{INTRODUCTION}

Microtus cabrerae (Cabrera's vole) is an endemic arvicoline restricted to the Iberian Peninsula. This vole was first described by Thomas (1906) on the basis of a specimen from the Sierra de Guadarrama (Madrid). Subsequently, Miller (1910) described the species Microtus dentatus on the basis of a specimen very similar to that described by Thomas (1906) as Microtus cabrerae. Cabrera (1914) continued to maintain the validity of the two species, whereas Niethammer et al. (1964) regarded M. cabrerae as a differentiated species and populations previously assigned to $M$. dentatus as a doubtful subspecies. Both studies of population genetic differentiation (Cabrera-Millet et al., 1982) and morphological studies (Ayarzagüena \& López-Martínez, 1976; Ventura et al., 1997) show the homogeneity of $M$. cabrerae populations and suggest that there are no reasons for a specific differentiation of $M$. dentatus. From an evolutionary point of view, $M$. cabrerae has been associated with the Middle Pleistocene fossil species $M$. brecciensis, and both species are included by Chaline (1972) in the subgenus Iberomys. CabreraMillet et al. (1983) considered the subgenus to be made up exclusively of $M$. (I.) brecciensis and $M$. (I.) cabrerae, which would constitute an endemic Ibero-Occitan line with more robust forms adapted to Mediterranean conditions and whose evolution would have taken place only in the Iberian Peninsula and southern France. It is possible to observe a closer relationship between these two species that suggests a linear evolution from one species to the other in the small time interval corresponding to the Late Pleistocene. On the other hand, the Cabrera vole currently shows a relict distribution, given the existence of subfossil sites outside its current range (Fig. 1). Several hypotheses have been put forward to explain the retraction of the $M$. (I.) cabrerae distribution area: 1) Cabrera-Millet et al. (1983) suggested that the retraction of the species took place in the Bronze Age and was provoked mainly by climatic factors; 2) another possible explanation for the retraction is the human impact on the landscape caused by agricultural development, which, as suggested by Férnandez-Salvador (1998) and Landete-Castillejos et al. (2000), would have caused the degradation of the species habitat; 3) another possible cause of the retraction of $M$. (I.) cabrerae is competition with other species, more specifically its direct competition with Arvicola sapidus (the southern water vole), which might have used very similar habitats to those used by the Cabrera vole (Pita et al., 2006).

Taking into account this background, the principal aim of this paper is to discuss the different hypotheses for the changes in distribution of the species $M$. (I.) cabrerae from the Late Pleistocene and beginning of the Holocene to the present and to try to ascertain which of these hypotheses is most tenable.

\section{MATERIAL AND METHODS}

In order to discuss the geographical changes undergone by $M$. (I.) cabrerae we used the current distribution of the species taken from Shenbrot \& Krasnov (2005) (Fig. $1)$, together with data from previously published archaeopalaeontological sites of the Late Pleistocene and beginning of the Holocene where M. (I.) cabrerae occurs (Table 1; Fig. 1). The nomenclature used in the descriptions of the $M$. (I.) cabrerae teeth (first lower molars only) is that of van der Meulen (1973) (Fig. 2).

A description of the species $M$. (I.) cabrerae is not the objective of this paper, but we consider it is important to point out the main morphological features of the teeth that allow the species to be identified, as well as to highlight the geographical and stratigraphical distribution of the species. The lineage of the subgenus Iberomys has only one present-day representative, $M$. (I.) cabrerae. The first citations of the species stem from the beginnings of the Late Pleistocene, around 90 ka (López- García et al., 2008; Arsuaga et al., 2010). M. (I.) cabrerae descended from Microtus (I.) brecciensis, which is represented in the Middle Pleistocene of the Iberian Peninsula at various sites, such as Galeria, Gran Dolina (TD10) and Sima del Elefante (TE18-19) in Atapuerca, province of Burgos (Cuenca-Bescós et al., 1999, 2010b; LópezGarcía et al., 2011a), Ambrona in Soria (Sesé \& Soto, 2005), Bolomor in Valencia (Guillem-Calatayud, 2001), Valdocarros in Madrid (Sesé et al., 2011) and Mollet in Girona (Maroto et al., 2012). According to Ayarzagüena \& López-Martínez (1976), the species M. (I.) cabrerae is characterized in general by having a large, wide $\mathrm{m} 1$; reduction of the triangles of the anteroconid complex (ACC); a long, narrow fifth lingual salient angle (LSA5), which according to Cuenca-Bescós et al. (1995) is a measure of its lateromedial asymmetry; a fourth buccal salient angle (BSA4) that is triangular-quadrangular in shape; and enamel that covers virtually all the labial wall of the ACC (Figs 2-3).

$M$. (I.) cabrerae is endemic to the Iberian Peninsula. Its current distribution is fragmentary, occupying various main nuclei in the foothills of the Pyrenees, the southern Iberian System, the Betic Sierras, and the Central System. The species is also present in the southern half of Portugal (Fig. 1). It inhabits exclusively Mediterranean areas. The species requires grassy cover all year round, with a high water table. Its altitudinal range is from 250 to $1500 \mathrm{~m}$. The species is broadly distributed in the Late Pleistocene and at the beginning of the Holocene of the Iberian Peninsula (Fig. 1), with the exception of the northern part of the Peninsula (López-García, 2011). 


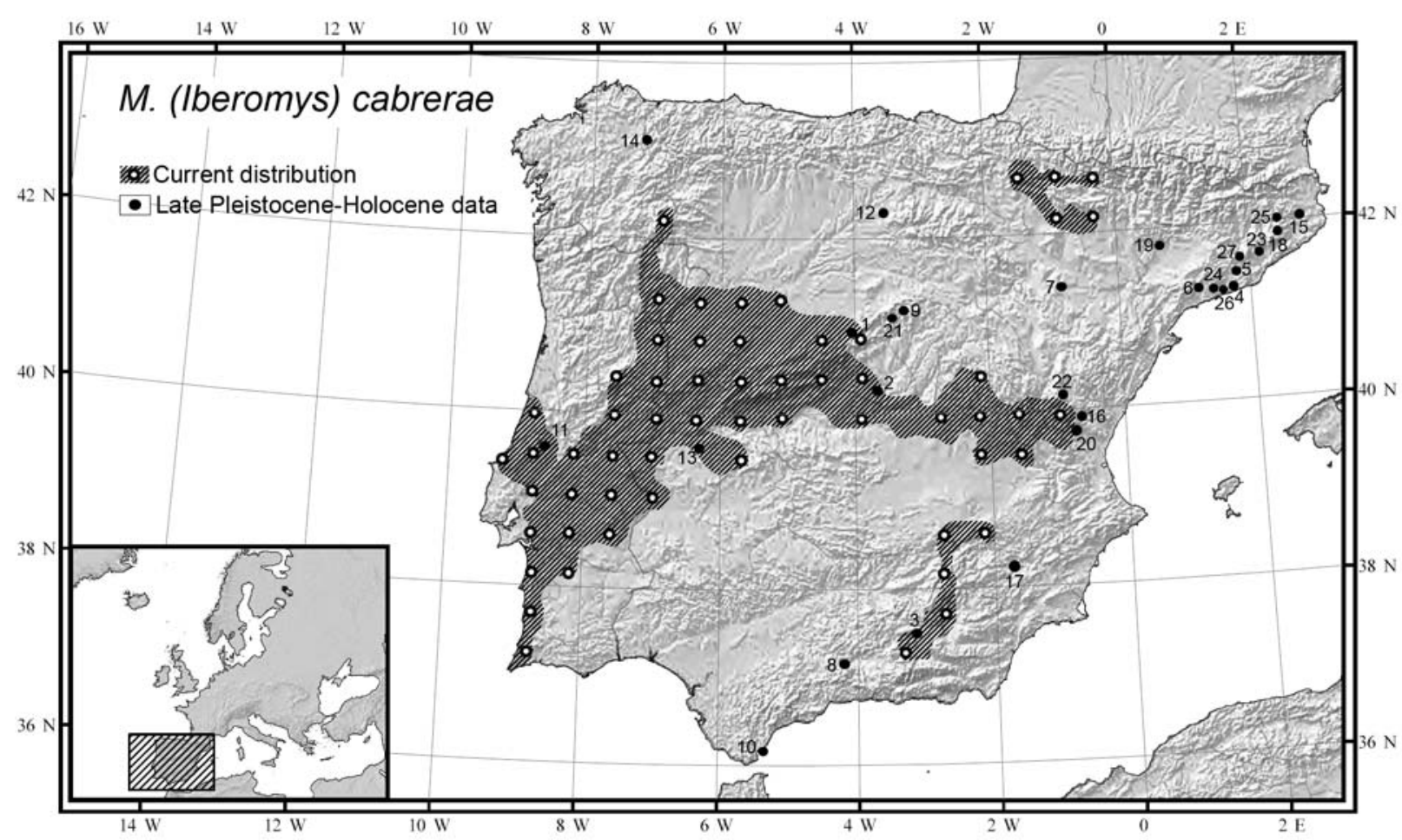

Figure 1. Current and Late Pleistocene-Holocene distribution of Microtus (Iberomys) cabrerae. 1. Camino; 2. HAT; 3. C. Horá; 4. C. Gegant; 5. A. Romaní; 6. Xaragalls; 7. Aguilón; 8. Zafarraya; 9. Zarzamora; 10. Gorham's; 11. Caldeirao; 12. El Portalón; 13. Chimeneas; 14.Valdavara-1; 15. l'Arbreda; 16. Cendres; 17. Baños de Mula; 18. Cingle Vermell; 19. C. Colomera; 20. La Sarsa; 21. La Ventana; 22. Bolumini; 23. El Frare; 24. Cova Foradada; 25. Cova 120; 26. Alorda Park; 27. Coves del Toll (Teixoneres and Toll caves).

\section{RESULTS AND DISCUSSION}

As noted above, the species $M$. (I.) cabrerae is broadly distributed in the Late Pleistocene and beginning of the Holocene outside its current distribution range (Fig. 1). The species has been recovered from several sites in Catalonia from the Late Pleistocene to the beginning of the Holocene, and in southeastern, south, central and northwestern Iberia during the Late Pleistocene (Fig. 1; Table 1). In this section we discuss the possible causes that have led to these changes in geographical distribution.

\subsection{Climatic factors}

One of the first hypotheses postulated by Cabrera-Millet et al. (1983) is that the retraction of the species to form its current geographical distribution took place in the Bronze Age and was caused mainly by climatic factors. Six rapidcooling climatic fluctuations during the Holocene have been detected, principally associated with orbital variations and solar variability (Mayewski et al., 2004). One of these fluctuations, occurring between 6,000-5,000 yr BP, coincided in the Northern Hemisphere with the beginning of the Bronze Age (ca. 5,000 yr BP). The Cabrera vole is typically from Mesomediterranean bioclimatic zones in Iberia (Rivas-Martínez, 1981) and is a habitat specialist with very demanding ecological requirements, the most important of which concerns humidity (Pita et al., 2006). Despite its strict ecological requirements, $M$. (I.) cabrerae survived the extremely cold climatic conditions of the Late Pleistocene (Last Glacial Maximum), during which it is represented at some sites within its current geographical range, such as Chimeneas (Extremadura) (Bañuls et al., 2012), and at some sites outside its present range, such as El Portalón (Burgos), Valdavara-1 (Lugo) (López-García et al., 2010a, 2011b) and Cova del Toll level 3 (FernándezGarcía \& López-García, 2012). Furthermore, taking into account the subfossil data, the species $M$. (I.) cabrerae persists outside its current geographical range through to the cold interval of the Bronze Age (6,000-5,000 yr BP) and is represented at the Iron Age site of Alorda Park (Catalonia). It seems to disappear from this region in the course of the 20th century (Valenzuela et al., 2009) (Fig. 1; Table 1). 
Table 1. Chronology and position of the principal sites with presence of Microtus (Iberomys) cabrerae.

\begin{tabular}{|c|c|c|c|c|c|}
\hline Series & $\begin{array}{l}\text { Cultural } \\
\text { Age }\end{array}$ & $\begin{array}{l}\mathrm{Ka} \\
\mathrm{BP}\end{array}$ & Sites & Layers & Authors \\
\hline \multirow{13}{*}{ 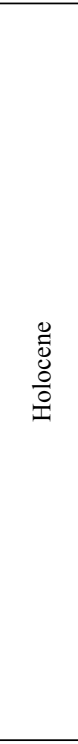 } & Iron Age & 2.1 & Alorda Park & & $\begin{array}{l}\text { Valenzuela et al., } \\
2009\end{array}$ \\
\hline & \multirow{6}{*}{$\begin{array}{l}\text { Bronze } \\
\text { Age }\end{array}$} & 3.1 & Cova 120 & II-I & Alcalde, 1986 \\
\hline & & $3.9-3.4$ & Colomera & EE1-Asup & $\begin{array}{l}\text { López-García et al., } \\
2010 b\end{array}$ \\
\hline & & $4.4-3.9$ & El Frare & $4-3$ & Alcalde, 1986 \\
\hline & & 4.4 & Valdavara-1 & UU & $\begin{array}{l}\text { López-García et al., } \\
\text { 2011b }\end{array}$ \\
\hline & & 4.7 & Cendres & III-I & $\begin{array}{l}\text { Guillem-Calatayud, } \\
1999\end{array}$ \\
\hline & & & C. Foradada & & Allué et al., 2012 \\
\hline & \multirow{6}{*}{ Neolithic } & $6.3-5.8$ & El Frare & $6-5$ & Alcalde, 1986 \\
\hline & & $7.5-6$ & Cendres & VII-IV & $\begin{array}{l}\text { Guillem-Calatayud, } \\
1999\end{array}$ \\
\hline & & & Bolumini & V-IV & $\begin{array}{l}\text { Guillem-Calatayud, } \\
1999\end{array}$ \\
\hline & & & La Ventana & & Sánchez et al., 2005 \\
\hline & & 6.9 & La Sarsa & & Sevilla, 1988 \\
\hline & & 7 & Colomera & CE13-14/12 & $\begin{array}{l}\text { López-García et al., } \\
2010 \text { b }\end{array}$ \\
\hline \multirow{22}{*}{ 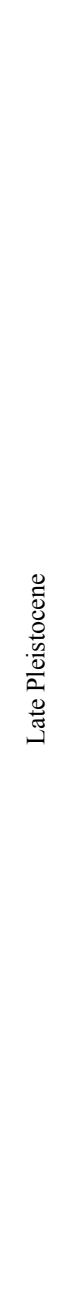 } & & 9.7 & Cingle Vermell & & Alcalde, 1986 \\
\hline & & $9.7-13$ & Toll & 2 & $\begin{array}{l}\text { Fernández-García } \\
\text { \& López-García } \\
2012\end{array}$ \\
\hline & & & \multicolumn{2}{|l|}{ Baños de Mula } & Agustí et al., 1990 \\
\hline & & & Cendres & XIIb-IX & $\begin{array}{l}\text { Guillem-Calatayud } \\
1999\end{array}$ \\
\hline & & & L'Arbreda & A & Alcalde, 1986 \\
\hline & & $15-13$ & Valdavara-1 & $\mathrm{LU}$ & $\begin{array}{l}\text { López-García et al., } \\
\text { 2011b }\end{array}$ \\
\hline & & $18-10$ & Gorham's & III & $\begin{array}{l}\text { López-García et al., } \\
2011 \mathrm{c}\end{array}$ \\
\hline & & 18 & Chimeneas & A & Bañuls et al., 2012 \\
\hline & & $30-16$ & Portalón & P16-P1 & $\begin{array}{l}\text { López-García et al., } \\
\text { 2010a }\end{array}$ \\
\hline & & $30-18$ & Caldeirao & $\mathrm{K}-\mathrm{Eb}$ & Povoas et al., 1992 \\
\hline & & $33-23$ & Gorham's & IV & $\begin{array}{l}\text { López-García et al., } \\
2011 \mathrm{c}\end{array}$ \\
\hline & & 33 & Zarzamora & $1-3$ & Sala et al., 2011 \\
\hline & & $35-13$ & Toll & 3 & $\begin{array}{l}\text { Fernández-García } \\
\text { \& López-García } \\
2012\end{array}$ \\
\hline & & & Zafarraya & & $\begin{array}{l}\text { Barroso Ruiz et al., } \\
2003\end{array}$ \\
\hline & & 41 & Aguilón & & $\begin{array}{l}\text { Cuenca-Bescós et } \\
\text { al., 2010a }\end{array}$ \\
\hline & & $45-48$ & Xaragalls & $\mathrm{C} 6-\mathrm{C} 4$ & $\begin{array}{l}\text { López-Garcia et al., } \\
2012 b \\
\text { López-García \& }\end{array}$ \\
\hline & & $58-44$ & A. Romaní & D-O & $\begin{array}{l}\text { Cuenca-Bescós } \\
2010\end{array}$ \\
\hline & & $60-50$ & C. Gegant & III-V & $\begin{array}{l}\text { López-García et al., } \\
\text { 2012a }\end{array}$ \\
\hline & & & Horá & XVIII-XII & García 1979 \\
\hline & & 74 & HAT & & Sesé et al., 2011 \\
\hline & & $90-60$ & Teixoneres & III & $\begin{array}{l}\text { López-García et al., } \\
2012 \mathrm{c}\end{array}$ \\
\hline & & 98.8 & Camino & 5 & Arsuaga et al., 2010 \\
\hline
\end{tabular}

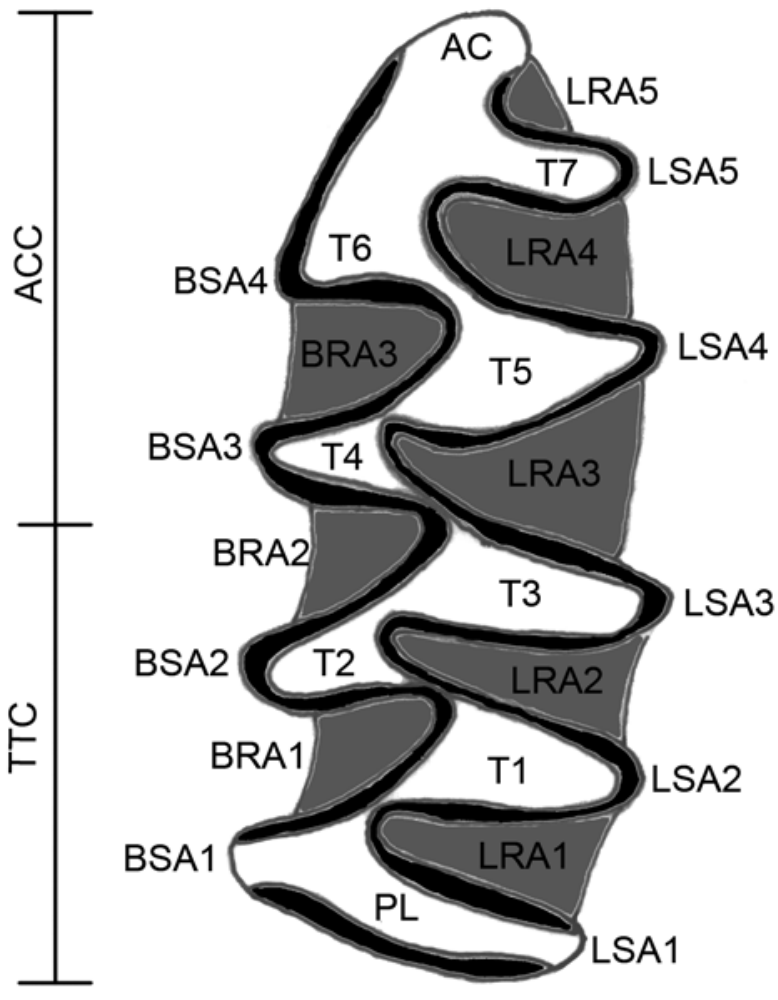

Figure 2. Nomenclature for the first lower molars (taken from van der Meulen 1973) in the description of Microtus (Iberomys) cabrerae. ACC, anteroconid complex; AC, anterior cap; BRA, buccal re-entrant angle; BSA, buccal salient angle; LRA, lingual re-entrant angle; LSA, lingual salient angle; PL, posterior lobe; TTC, trigonid-talonid complex, T1-T7, triangles.

\subsection{Human impact}

As noted above, $M$. (I.) cabrerae is an endemic habitat specialist with very demanding ecological requirements; it requires a type of vegetation that remains green all year round (within Mediterranean conditions) and is sufficiently tall enough to provide effective protection against predators. These environmental requirements lead the Cabrera vole to establish its colonies in biotopes characterized by well-developed soils with a high degree of humidity and located mainly on plain zones. These biotopes are at the same time sites that are potentially suitable for agriculture (Fernández-Salvador, 1998). As suggested by Landete-Castillejos et al. (2000), the developments in agriculture over the last 30 years, along with the increase in road infrastructures and human population, may well have destroyed the potential habitats of the species. This is the cause pinpointed by Valenzuela et al. (2009) for the disappearance of the species from Catalonia over the course of the 20th century. 


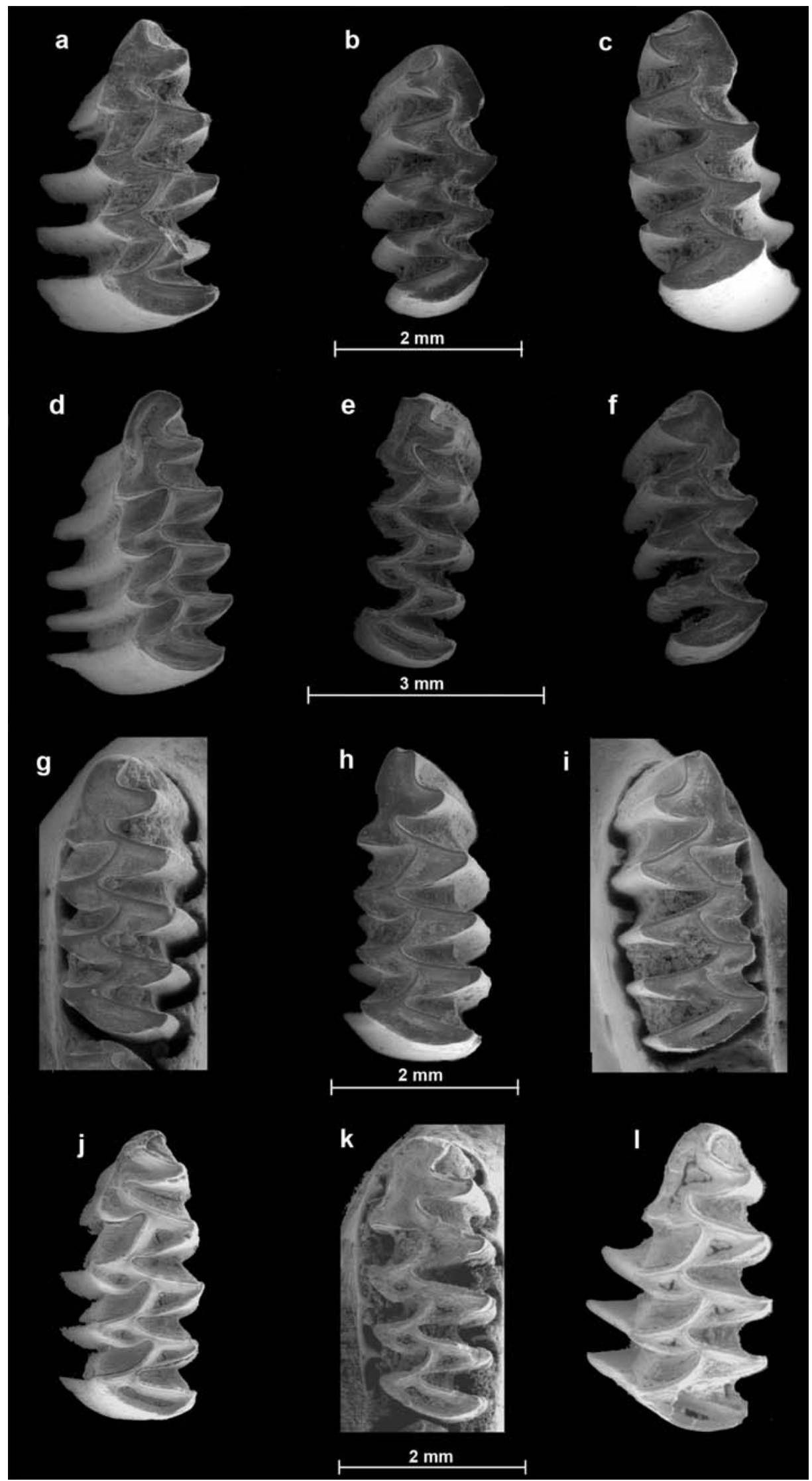

Figure 3. Some Microtus (Iberomys) cabrerae teeth from the sites mentioned in text. a-c) first lower molars ( $\mathrm{m} 1)$ from the C. Gegant. a: $\mathrm{m} 1$ left. b-c: $\mathrm{m} 1$ right. d-f) $\mathrm{m} 1$ from Gorham's cave; d-e: $\mathrm{m} 1$ left; f: $\mathrm{m} 1$ right. g-l) $\mathrm{m} 1$ from A. Romaní; g-h: $\mathrm{m} 1$ left; i: $\mathrm{m} 1$ right; $\mathbf{j}-\mathrm{l}: \mathrm{m} 1 \mathrm{left}$. All teeth are in occlusal view. 


\subsection{Competition with other species}

Finally, studies of current populations of the Cabrera vole support the possibility of competition between this species and the southern water vole (Arvicola sapidus). Pita et al. (2006) show that at sites where one species is present, the other is always absent. Findings by Fedriani et al. (2002) on the habitat requirements for the southern water vole suggest that this species might use very similar habitats to those used by the Cabrera vole. Regarding the subfossil data, however, there does not seem to be direct competition between the Cabrera vole and the southern water vole, given that the two species appear together at 17 (Camino, HAT, Horá, Romaní, Xaragalls, Zarzamora, Gorham's, Caldeirao, Portalón, Chimeneas, Valdavara-1, l'Arbreda, Cendres, Baños de Mula, Cingle Vermell, Bolumini and Cova 120) of the 26 Late Pleistocene and Holocene sites exposed (Table 1). These results seem to lend support to Fernández-Salvador's (1998) hypothesis that southern water voles would occupy the banks of rivers and other water bodies, while the Cabrera vole would be established in the vicinity of ditches and creek margins, but without going into the banks that Arvicola sapidus occupy.

\section{CONCLUDING REMARKS}

This study of the geographical changes undergone by the species $M$. (I.) cabrerae allows us to establish that the most plausible hypothesis for the retraction of its distribution during the Late Pleistocene and beginning of the Holocene is the human impact, which has destroyed the habitat of the species with the development of agriculture, road infrastructures and increasing human population.

\section{ACKNOWLEDGMENTS}

This paper is part of projects CGL2009-07896, CGL200912703-C03-03, and SGR2009-324. We also grateful thank to Dr. Robert Martin, Dr. Adam Nadachowski and Dr. Xabier Murelaga for their comments. J.M.L-G. has been supported by a postdoctoral grant from the Juan de la Cierva Subprogram (JCI-2009-04026), with the financial sponsorship of the Spanish Ministry of Science and Innovation.

\section{REFERENCES}

Agustí, J., Freudenthal, M., Lacomba, J.I., Martín Suárez, E. \& Nägeli, C. 1990. Primeros micromamíferos del Pleistoceno Superior de la Cuenca de Mula (Murcia, España). Revista de la Sociedad Geológica de España, 3, 289-293.
Alcalde, G. 1986. Les Faunes de Rongeurs du Pléistocène Supérieur et de l'Holocène de Catalogne (Espagne) et leurs Significations Paléoècologiques et Palèoclimatiques. Diplôme E.P.H.E., Paris.

Allué, E., Burjachs, F., García, A., López-García, J.M., Bennàsar, M., Rivals, F., Blain, H.-A., Expósito, I. \& Martinell, J. 2012. Neanderthal landscapes and their home environment: Flora and fauna records from Level J. In: High Resolution Archaeology and Neanderthal Behavior: Time and Space in Level J of the Abric Romani (Capellades, Spain) (ed. Carbonell, E.). Springer, UK, 135-157.

Arsuaga, J.L., Baquedano, E., Pérez-González, A., Sala, M.T.N., García, N., Álvarez-Lao, D., Laplana, C., Huguet, R., Sevilla, P., Blain, H.-A., Quam, R., Ruiz-Zapata, M.B., Sala, P., García, M.J.G., Uzquiano, P. \& Pantoja, A. 2010. El yacimiento arqueo-paleontológico del Pleistoceno Superior de la Cueva del Camino en el Calvero de la Higuera (Pinilla del Valle, Madrid). Zona Arqueológica, $13,422-442$.

Ayarzagüena, J. \& López-Martínez, N. 1976. Estudio filogenético y comparativo de Microtus cabrerae y Microtus brecciensis. Doñana Acta Vertebrata, 3, 181-204.

Bañuls, S., López-García, J.M., Blain, H.-A. \& Canals, A. 2012. Climate and landscape during the Last Glacial Maximum in southwestern Iberia: the small vertebrate association from the Sala de las Chimeneas, Maltravieso, Extremadura. Comptes Rendus Palevol, 11, 31-40.

Barroso Ruíz, C., Abassi, M., Bailon, S., Cheylan, M., Desclaux, E., El Gennouni, K., Fons, R., Haquart, A, Fernandez Carrasquilla, F., Moigne, A.M., Poitevin, F., Prodon, R. \& Vilette, Ph. 2003. Tafonomía: Significación paleobiogeográfica, paleoecológica y paleoclimática de las faunas de microvertebrados del Pleistoceno Superior de la Cueva del Boquete de Zafarraya. In: Monografía del Boquete de Zafarraya (ed. Barroso Ruíz, C.). Junta de Andalucía, Granada, 289-299.

Cabrera, A. 1914. Fauna Ibérica. Mamíferos. Museo Nacional de Ciencias Naturales. Madrid.

Cabrera-Millet, M., Britton-Davidian, J. \& Orsini, P. 1982. Génétique biochimique comparée de Microtus cabrerae Thomas 1906 et de trois autres espèces d'Arvicolidae méditerranéens. Mammalia, 46, 381-388.

Cabrera-Millet, M., López-Martínez, N. \& Michaux, J. 1983. Un exemple de ligne endemique iberoccitane, les champagnols Microtus brecciensis et Microtus cabrerae (Mammalia, Rodentia). Etude phylogenetique et contexte ecologique d'un phenomene evolutif recent. In: Actes $d u$ symposium paléontologique G. Cuvier (eds. Buffereaut, E., Mazin, J.M. \& Salmon, E.), 69-83.

Chaline, J. 1972. Les Rongeurs du Pléistocène Moyen et Supérieur de France. Systématique, Biostratigraphie, Paléoclimatologie. Cahiers Paléontologie C.N.R.S., Paris.

Cuenca-Bescós, G., Canudo, J.I. \& Laplana, C. 1995. Los arvicólidos (Rodentia, Mammalia) de los niveles inferiores de Gran Dolina (Pleistoceno inferior, Atapuerca, Burgos, España). Revista Española de Paleontología, 10, 202218. 
Cuenca-Bescós, G., Canudo, J.I. \& Laplana, C. 1999. Análisis bioestratigráfico de los roedores del Pleistoceno medio del yacimiento de Galeria (Sierra de Atapuerca, Burgos). In: Atapuerca: Ocupaciones Humanas y Paleoecología del Yacimiento de Galeria (eds. Carbonell, E., Rosas, A. \& Díez Fernández-Lomana, J.C.). Burgos, Junta de Castilla y León, 189-210.

Cuenca-Bescós, G., Martínez, I., Mazo, C., Sauqué, V., Ramón-del Rio, D., Rabal-Garcés, R. \& Canudo, J.I. 2010a. Nuevo yacimiento de vertebrados del Cuaternario del Sur del Ebro en Aguilón, Zaragoza, España. III Congreso Ibérico de Paleontología, 106-108.

Cuenca-Bescós, G., Rofes, J., López-García, J.M., Blain, H.-A., De Marfá, R.J., Galindo-Pellicena, M.A., BennásarSerra, M.Ll., Melero-Rubio, M., Arsuaga, J.L., Bermúdez de Castro, J.M. \& Carbonell, E. 2010b. Biochronology of Spanish Quaternary small vertebrate faunas. Quaternary International, 212, 109-119.

Fedriani, J.M., Delibes, M., Ferraras, P. \& Roman, J. 2002. Local and landscape habitat determinants of water vole distribution in a patchy Mediterranean environment. Ecoscience, 9, 12-19.

Fernández-García, M., \& López-García, J.M. 2012. Resultados preliminares del estudio de los roedores del Pleistoceno Superior-Holoceno de la cueva del Toll (Moià, Barcelona). In: Paleodiversity and Palaeoecology of Iberian Ecosystems (eds. Martínez-Pérez, C., Furió, M., Santos-Cubedo, A. \& Poza, B). Ministerio de Economía y Competitividad, Valencia, 122-125.

Fernández-Salvador, R. 1998. Topillo de Cabrera, Microtus cabrerae Thomas, 1906. Galemys, 10, 5-18.

García, C. 1979. Los roedores de Cueva Horá (Darro, Granada). Nuevos datos sobre la fauna del Pleistoceno Superior de Andalucía. In: El Yacimiento Musteriense de Cueva Horá (Darro, Granada). Primeros resultados. (eds. Botella, M.C. \& Martínez, C.). Antropología y Paleoecología Humana, 1, 1-10.

Guillem-Calatayud, P.M. 1999. Los micromamíferos (Rodentia, Insectívora y Chiroptera) de la Secuencia Holocena de la Cova de les Cendres y Cova Bolumini. Saguntum-PLAV, Extra-2, 31-36.

Guillem-Calatayud, P.M. 2001. Los micromamíferos y la secuencia climática del Pleistoceno Medio, Pleistoceno Superior y Holoceno, en la fachada central mediterránea. In: De Neandertales a Cromañones. El Inicio del Poblamiento Humano en las Tierras Valencianas (ed. Villaverde, V.). Universidad de Valencia, Valencia, 5772.

Landete-Castillejos, T., Andrés-Abellán, M., Aragandoña, J.J. \& Garbe, J. 2000. Distribution of the Cabrera vole (Microtus cabrerae) in its first reported areas reassessed by live trapping. Biological Conservation, 94, 127-130.

López-García, J.M. 2011. Los Micromamíferos del Pleistoceno Superior de la Península Ibérica. Evolución de la Diversidad Taxonómica y Cambios Paleoambientales y Paleoclimáticos. Editorial Académica Española, Saarbrücken.
López-García, J.M. \& Cuenca-Bescós, G. 2010. Evolution climatique durant le Pléistocène Supérieur en Catalogne (Nord-est de l'Espagne) d'après l'étude des micromammifères. Quaternaire, 21, 249-258.

López-García, J.M., Blain, H.-A., Cuenca-Bescós, G. \& Arsuaga, J.L. 2008. Chronological, environmental and climatic precisions on the Neanderthal site of the Cova del Gegant (Sitges, Barcelona, Spain). Journal of Human Evolution, 55, 1151-1155.

López-García, J.M., Blain, H.-A., Cuenca-Bescós, G., RuizZapata, M.B., Dorado- Valiño, M., Gil-García, M.J., Valdeolmillos, A., Ortega, A.I., Carretero, J.M., Arsuaga, J.L., Bermúdez de Castro, J.M. \& Carbonell, E. 2010a. Palaeoenvironmental and palaeoclimatic reconstruction of the Latest Pleistocene of El Portalón Site, Sierra de Atapuerca, northwestern Spain. Palaeogeography, Palaeoclimatololgy, Palaeoecology, 292, 453-464.

López-García, J.M., Blain, H.-A., Allué, E., Bañuls, S., Bargalló, A., Martín, P., Morales, J.I., Pedro, M., Rodríguez, A., Solé, A. \& Oms, F.X. 2010b. First fossil evidence of an "interglacial refugium" in the Pyrenean region. Naturwissenschaften, 97, 753-761.

López-García, J.M., Blain, H.-A., De Marfà, R., Garcia, A., Martinell, J., Bennàsar, M.Ll. \& Cuenca-Bescós, G. 2011a. Small mammals from the middle Pleistocene layers of the Sima del Elefante (Sierra de Atapuerca, Burgos, northwestern Spain). Geologica Acta, 9, 21-43.

López-García, J.M., Blain, H.-A., Cuenca-Bescós, G., Alonso, C., Alonso, S. \& Vaquero, M. 2011b. Small vertebrates (Amphibia, Squamata, Mammalia) from the late Pleistocene-Holocene of the Valdavara-1 cave (Galicia, northwestern Spain). Geobios, 44, 253-269.

López-García, J.M., Cuenca-Bescós, G., Finlayson, C., Brown, K. \& Giles Pacheco, F. 2011c. Palaeoenvironmental and palaeoclimatic proxies of the Gorham's cave small mammal sequence, Gibraltar, southern Iberia. Quaternary International, 243, 137-142.

López-García, J.M., Blain, H.-A., Sanz, M. \& Daura, J. 2012a. A coastal reservoir of terrestrial resources for Neanderthal populations in north-eastern Iberia: palaeoenvironmental data inferred from the small-vertebrate assemblage of Cova del Gegant, Sitges, Barcelona. Journal of Quaternary Science, 27, 105-113.

López-García, J.M., Blain, H.-A., Bennàsar, M., Euba, I., Bañuls, S., Bischoff, J., López-Ortega, E., Saladié, P., Uzquiano, P. \& Vallverdú, J. 2012b. A multiproxy reconstruction of the palaeoenvironment and palaeoclimate of the Late Pleistocene in northeastern Iberia: Cova dels Xaragalls, Vimbodí-Poblet, Paratge Natural de Poblet, Catalonia. Boreas, 41, 235-249.

López-García, J.M., Blain, H.-A., Burjachs, F., Ballesteros, A., Allué, E., Cuevas-Ruiz, G.E., Rivals F., Blasco, R., Morales, J.I., Rodríguez Hidalgo, A., Carbonell, E., Serrat, D. \& Rosell, J. 2012c. A multidisciplinary approach to reconstructing the chronology and environment of southwestern European Neanderthals: the contribution of Teixoneres cave (Moià, Barcelona, Spain). Quaternary Science Reviews, 43, 33-44. 
Maroto, J., Julià, R., López-García, J.M. \& Blain, H.-A 2012. Chronological and environmental context of the Middle Pleistocene human tooth of Mollet cave (Serinyà, NE Iberian Peninsula). Journal of Human Evolution, 62, 655-663.

Mayewski, P.A., Rohling, E.E., Stager, C., Karlén, W. Maasch, K.A., Meeker, L.D., Meyerson, E.A., Gasse, F., van Kreved, S., Holmgren, K., Lee-Throp, J., Rosqvist, G., Rack, F., Staubwasser, M., Schneider, R.R. \& Steig, E.J. 2004. Holocene climate variability. Quaternary Research, 62, 243-255.

Meulen, A.J., van der. 1973. Middle Pleistocene smaller mammals from the Monte Peglia (Orvieto, Italy) with special reference to the phylogeny of Microtus (Arvicolidae, Rodentia). Quaternaria, 17, 1-144.

Miller, G.S. 1910. Description of six new European mammals. Annals and Magazine of Natural History, Series 8, 6, 458-461.

Niethammer, J., Niethammer, G. \& Abs, M. 1964. Ein Beitrag zur Kenntnis der Cabreramaus (Microtus cabrerae Thomas, 1906). Bonner zoologische Beiträge, 15, 127148 .

Pita, R., Mira, A. \& Beja, P. 2006. Conserving the Cabrera vole, Microtus cabrerae, in intensively used Mediterranean landscapes. Agriculture Ecosystems \& Environment, 115, $1-5$.

Povoas, L., Zilhao, J., Chaline, J. \& Brunet-Lecomte, P. 1992. La faune de rongeurs du Pleistocene superieur de la grotte de Caldeirao (Tomar, Portugal). Quaternaire, 3, 40-47.

Rivas-Martínez, S. 1981. The vegetation of bioclimatic stages of Iberian Peninsula. Anales del Jardín Botánico de Madrid, 37, 251-268.

Sala, N.M.T., Arsuaga, J.L., Laplana, C., Ruiz Zapata, B., Gil García, M. J., García, N., Aramburu, A. \& Algaba, M. 2011. Un paisaje de la Meseta durante el Pleistoceno superior. Aspectos paleontológicos de la Cueva de la Zarzamora (Segovia, España). Boletín de la Real Sociedad Española de Historia Natural, 105, 67-85.
Sánchez, A., Fraile, S., van der Made, J., Morales, J., Quiralte, V., Salesa, J.M., Sánchez, M.I., Sanchiz, B., Soria, D., Jiménez, J., Barbadillo, J., Laplana, C. \& Szyndlar, Z. 2005. Primeros datos faunísticos del Neolítico madrileño: la cueva de la Ventana (Torrelaguna, Madrid). In: Actas III Congreso de Neolítico en la Península Ibérica (eds. Arias Cabal, P., Ontanón Peredo, R. \& Moncó Piñeiro, C.). Universidad de Cantabria, Cantabria, 155-165.

Sesé, C. \& Soto, E. 2005. Mamíferos del yacimiento del Pleistoceno Medio de Ambrona: Análisis faunístico e interpretación paleoambiental. In: Los Yacimientos Paleolíticos de Ambrona y Torralba (Soria). Un Siglo de Investigaciones Arqueológicas (eds. Santonja, M. \& Pérez González, A.). Zona Arqueológica, 15, Museo Arqueológico Regional, Alcalá de Henares, 258-280.

Sesé, C., Panera, J., Rubio-Jara, S. \& Pérez-González, A. 2011. Micromamíferos del Pleistoceno Medio y Pleistoceno Superior en el Valle del Jarama: yacimientos de Valdocarros y HAT (Madrid, España). Estudios Geológicos, 67, 131-151.

Sevilla, P. 1988. Estudio Paleontológico de los Quirópteros del Cuaternario Español. Paleontología i Evolució, 22, 113-233.

Shenbrot, G.I. \& Krasnov, B.R. 2005. An Atlas of the Geographic Distribution of the Arvicoline Rodents of the World (Rodentia, Muridae: Arvicolinae). Pensoft, Sofia-Moscow.

Thomas, O. 1906. A new vole from Spain. Annals and Magazine of Natural History, 7, 576-577.

Valenzuela, S., Poitevin, F., Cornette, R., Bourney, A., Nadal, J. \& Vigne, J.-D. 2009. Evolving ecosystems: ecological data from an Iron Age small mammal accumulation at Alorda Park (Catalonia, Spain). Journal of Archaeological Science, 36, 1248-1255.

Ventura, J.M., López-Fuster, M.J. \& Cabrera, M. 1997. The Cabrera vole, Microtus cabrerae, in Spain: a biological and a morphometric approach. Netherlands Journal of Zoology, 47, 1-18. 